\title{
Hersch Lauterpacht: A Powerful Eastern European Figure in International Law
}

\author{
Anthony Carty*
}

\section{Contents}

1. Introduction

2. Private Law Sources and Analogies of International Law, Aspects.

3. A Teutonic Aversion to Acquisitive Prescription?

4. The Reality of the State - A German Idea or a European Heritage

5. Private Law Analogy: Could Lauterpacht Have Addressed Standards of International Morality More Directly?

\section{Introduction}

The symposium to which Lauri Mälksoo kindly invited me in Tartu at the end of April 2006 was a remarkable experience. Leading academics from Eastern Europe have given very varied and exhaustive accounts of the contribution (Linda: i.e. here: to the European traditions of international law) which scholars, from what was the other side of the Iron Curtain, had made to the European traditions of international law. Vivid memories of the Russian and Soviet Empires were everywhere to be seen in Tartu, and Lauri Mälksoo's own contribution on von Bulmerincq showed also the pervasive German influence in Eastern Europe. My contribution will be not dissimilar to the latter as I will explore aspects of the manner in which Hersch Lauterpacht dealt with German traditions of international law as he made the transition from Austria-Hungary to London in the immediate aftermath of the First World War. My approach will not be biographical, but concentrate instead upon a textual exposition and critical reflection upon aspects of Hersch Lauterpacht's Private Law Sources and Analogies of International Law.1 I think that such an exercise is particularly valuable at the present time, now that most parts of Europe, not Russia or the Ukraine, are together in the same economic and political union. In my view, a small but not insignificant part

* Professor of Public Law, University of Aberdeen

1 (Longmans, London, 1927). With special reference to international arbitration.

[end of page 83]

of the task of evolving common European approaches to international law is to search out the influences brought about by past migrations of scholars across Europe.

In a wider context, even apart from the holding of the conference in Tartu, it is a remarkable fact that there is a considerable increase in interest in the history of international law at the present time. One might speculate about this fact. Is the interest purely aesthetic, indeed romantic? The beautiful surroundings of Tartu, as an ancient European university city, and Tallinn, the capital of Estonia, encourage reflection on a much less troubled 
$19_{\text {th }}$ and early $20_{\text {th }}$ century and may lead us to ask whether we can leap back to these times of apparently common European cultural solidarity, when leading intellectuals and academics could move across state boundaries with relative ease, when multilingualism was normal and cultural barriers, at least within Europe, unimportant.

The interest in historical explorations can also be more pressing, attributable to a sense of crisis in the present discipline, attributable to the failure of the international legal order to rise to new challenges (such as the so-called War on Terrorism or Militant Islam), or perhaps even more seriously, a loss of continuity of the discipline with its spiritual, cultural or other traditions. In this case, it might be hoped that a return to historical roots could serve a purpose of renewal of foundations. It is very much in this last spirit that I intend to undertake a purely textual analysis of one of Lauterpacht's major works.

A first positive aspect of this exercise is that Lauterpacht identified a problem of international society, which is still with us - the very strong state that has a legal philosophy not appearing to encourage acceptance of a larger international legal order. In Lauterpacht's time that state was taken to be Germany, but the problem whether international legal culture can put up resistance to a single super-power remains. A second positive aspect of the exercise is the breadth of linguistic and philosophical culture Lauterpacht could bring to the analysis of an issue.

There are two more problematic aspects of his undertaking, which it is the predominant aim of this short article to argue. Firstly, Lauterpacht made a scapegoat out of Germany as a way of responding to the crisis of the overpowerful state. He treated German legal culture as monolithic and could not recognise the diversity and complexity of opinion within Germany. Equally he equated with Germany alone features of the legal philosophy of the state, which were part of a common European heritage, from which he purported to separate and single out Germany. Secondly, the remedy which

[end of page 84]

Lauterpacht offered, to overcome contemporary difficulties with the legal philosophy of the state, was to contribute significantly to the crisis that many agree international law faces at the present time, that it is a purely technical, even formalistic, discipline that does not have the wider legal humanistic resources to confront the crises that international society now faces. The article concludes by asking what if Lauterpacht had chosen to go, as he could have, in a different direction, making a different spiritual and cultural journey.

\section{Private Law Sources and Analogies of International Law, Aspects.}

Lauterpacht came to London in 1923 and the above title was his dissertation of 1927. In his comprehensive and systematic survey of Lauterpacht's work, while at the same time very brief consideration of the above volume, Koskenniemi sets out very clearly the ideological goals that Lauterpacht had, or at least is widely understood to have had. Law's unity is a scientific postulate, since law abhors a vacuum as much as physics. A topic must be considered as a totality, which can be done through analogy. Legal analogy resembles that used by scientists and logicians. In Koskenniemi's own words, "analogy is the lawyer's means of supplementing fragmentary or contradictory materials so as to ensure law's systemic unity".2 Liberal principles, in Koskenniemi's wider cultural argument, require appeal to such 
universal principles of science as logical consistency and correspondence with facts. Traditional legal positivism fails because it is logically incoherent. State will, as Koskenniemi summarises the argument, cannot be the ultimate source of law because one has still to look for a rule that the state will binds. 3

The heart of Lauterpacht's argument, as Koskenniemi rightly points out, is that positivism is at variance with the facts. Judges and arbitrators use municipal jurisprudence and general principles of law in a wide range of matters covering large areas of international law. Essentially they are using private law concepts. 4 This allows Koskenniemi to draw once again on his wider cultural perspective that scientism is accompanied by methodological individualism, a liberal political theory. The state cannot stand between the individual and the international legal order.5 Koskenniemi quotes

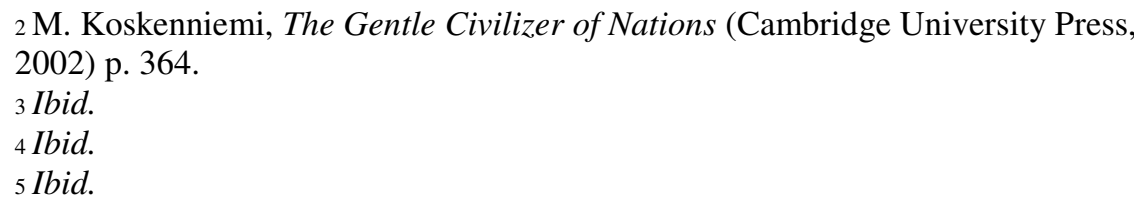

Lauterpacht from the book, concerning the supposed mystical nature of sovereignty, or the mystical nature of the relationship of state territory to the state. Instead the legal order can divide and limit the state. "All law has to do with regulating human behaviour; analogy is really but an aspect of the law's wholeness."6 All of this allows Lauterpacht to embark upon a "progressive" political programme, in Koskenniemi's words.7 The programme, quoting Koskenniemi, " puts the individual into the centre and views the State as a pure instrumentality. Behind nationalism and diplomacy the world remains a community of individuals and the rule of law is nothing other than the state of peace among them." 8

Supposedly, the ideological assumption might be made that private law analogies signify concern for private persons and individual welfare. However, this is precisely one of the major elisions of thought that my own small contribution will challenge. Lauterpacht himself does say that:

\footnotetext{
"The rejection of private law is, to a considerable extent, prompted by the conviction that the interests protected by international law are fundamentally different from those regulated by private law. It is the conviction embodied in that conception of the absolute value of the State, which, under the influence of the idealistic philosophy and political theory, was determining the trend of modern international law. The possibility of private law playing any part at all in the development of international law is therefore conditioned by a previous abandonment of that political aspect of the doctrine of sovereignty and by the acceptance of the view that acts of States and of their organs are actions of men, for ordinary human purposes, governed by standards of justice and morality accepted by States and their peoples within their territories, and that the interests of States are only in degree different from those protected by other collective bodies or from interests of individuals".9
}

Even further, it certainly appears that Lauterpacht regarded himself as an economic liberal, if not a methodological individualist. In the same part of the book he says, almost at once, that the interests of individuals are chiefly economic, but, at the same time, as a rule, in international relations, "the political activities of States in 
6 Ibid., p. 365, citing H. Lauterpacht, infra note 9, pp. 71-79.

7 Ibid.

${ }_{8}$ Ibid.

${ }_{9} \mathrm{H}$. Lauterpacht, Private Law Sources and Analogies of International Law

(Lawbook Exchange, Union, NJ, 2001) p. 72.

[end of page 86]

the field of international relations are primarily devoted to safeguarding collective economic interests, no matter under what disguise they happen to appear".10 Lauterpacht continues to insist that "between individuals, autonomous groups, and States there is a legal difference of degree only".11

In this part of my short article I wish simply to illustrate that Lauterpact was, in his unqualified acceptance of the legal validity of treaties and arbitrations, which were dominated by Western countries, in particular his own adopted country, Great Britain, a legal positivist, who accepted, without hesitation, the colonialist and imperialist legal policies of his new country. The central point is that the jurisprudence and treaty law to which Lauterpacht has recourse has no ethical affinity at all with the primacy of the individual. So he insists that the law of the acquisition of territory does come from a private law analogy, from Roman law, but all it comes to is a blank cheque for the colonial power. The principle dominating theory and practice of the law "is that based on the Roman law rules of possession, i.e. on the connection of animus with corpus, of the bodily act with the mental attitude".12 From Grotius, through Vattel, to the Berlin Declaration of 1885, Articles 34 and 35, the same principle asserts itself, the requirement of corpus and animus. "It was of the greatest importance as an ordering element in the development of international law in the period following the discovery of the New World."13

The reason Lauterpacht thinks private law analogy is effective is that it expresses what is for him the reality that territory is simply an object which states can acquire and dispose of as they please and not part of the elements that go up to make a viable community, i.e. to say a nation or other ethnic group which has historically been tied to a particular location, so that uprooting or otherwise removing it would be, in some sense, ethically problematic. Lauterpacht contrasts two theories of the legal nature of territorial sovereignty, the object theory and the space theory. The former theory, held mainly by Anglo-American international lawyers, such as Hall, Fenwick and Hyde, is that a state can be said to have a proprietary right over its territory, which it owns exclusively and may dispose of. This concept, primarily presented as Hall's, is not patrimonial as individuals are not subjects of international law, in Hall's view. Whether the theory is based upon dominium or imperium, in both cases, says Lauterpacht, "the territory

10 Ibid., p. 73.

11 Ibid.

12 Ibid., p. 100.

13 Ibid., p. 101.

Anthony Carty

[end of page 87]

is construed as an object of the State's right. And it is this 'object theory' which regards the relation of the State to its territory as identical with or as analogous to the private law right of property ..."14

The "space theory" rejects the view that the state can rule "over a lifeless 
object of nature, such as territory". The territory is instead an element of the state, and "it can no more be regarded as the object of a state's right, than the body of a man can be said to be his property. The territory is the space within which the jurisdiction of the state is exercised. The state rules within the territory, not over it." ${ }_{15}$ Germans hold this view, of course. Another German theory is the so-called "competence theory", that territorial sovereignty is a sum of the competences ratione loci which international law concedes to the state. The tone of Lauterpacht's scholarship is important to experience. It is dogmatic and authoritarian:
"It is not intended to discuss here this doctrine in detail. Unrelated as it is to the practice of states, it is not likely to be of lasting influence. It possesses, however the merit of having clearly demonstrated that the view which regards the territory as an element of the conception of state is untenable ...16
A cursory survey of the practice of governments with regard to modes of cession of territory will show that they have never ceased to regard the territory as an object of the state's right ..."17

This cursory survey, in Lauterpacht's view shows that "in numerous recent treaties, territories or spheres of influence have been mutually ceded in a way which vividly recalls to mind the character of exchange. The treaty of July 1890 between Great Britain and Germany relating to territory in East Africa and to Heligoland, and the agreement between France and Great Britain of April 1904 relating to Morocco and Egypt, may be quoted as examples." 18 Lauterpacht goes on to give various examples of territory transferred for the purpose of a pledge, such as the Japanese occupation of We-hai-wei as a guarantee of the Peace Treaty of Shimonoseki of 1895 and, of course, Article 428 of the Treaty of Versailles, providing for the Allied

\author{
14 Ibid., p. 92. \\ 15 Ibid., p. 93. \\ 16 Ibid., pp. 93, 94. \\ 17 Ibid., p. 96. \\ 18 Ibid., p. 97.
}

[end of page 88]

occupation of territory in Germany west of the Rhine for fifteen years, to secure performance of the Treaty. 19

\title{
3. A Teutonic Aversion to Acquisitive Prescription?
}

The engagement of Lauterpacht's scholarship can be seen in his arguments in favour of the acceptance of a place for acquisitive prescription in international law. Here he directs his rage against the most prominent German textbook writer on international law, Franz von Liszt. Lauterpacht quotes numerous British-American treaties, British, as well as Hague arbitrations, which support the doctrine of acquisitive prescription. He then goes on to single out von Liszt as someone opposed to his view. It is clear that for Lauterpacht no decent or reasonable person can be opposed to private law analogies in international law. In his own words:

"Stubborn opposition against this rule of private law could only come from writers who emphasise the fundamental difference between international and private law. In a community in which force constitutes right, and in which actual possession, regardless 
of time, confers a title, the institute of prescription is unnecessary. If no possession is illegal, if every possession is lawful, then clearly there is no need for a jural principle calculated to legalise an originally illegal position. This is, for instance, the view of Liszt, who speaks of the direct law-creating influence which mere force, especially conquest, has in the domain of international law. This opinion, although generally rejected, is nevertheless instructive as showing the theoretical sources from which the opposition to private law arises ..."20

What von Liszt actually said was that the notion of acquisitive prescription did not of itself have the character of a law creating fact. The first reason was the significance which attaches to the tacit consent of a state, which finds itself injured in its interests through a displacement (dislocation) in international relations. The second was the significance of force, where von Liszt makes clear mention of the absence of the usefulness of the private law analogy. There is no English translation of what he says, so I will have to offer a translation and summary. In my interpretation what he says is that in international law a state can acquire a foreign territory through force by going to war and without having to justify this act by providing a

19 Ibid., p. 98.

20 Ibid., p. 117.

[end of page 89]

justification of title in the sense which would be understand in private law, and without having to wait for a long passage of time. Von Liszt is saying that the essence of this possibility is the power of the conquering state, and, for the sake of understanding the reality of this process, it is not affected by the absence of a peace treaty. In my view this last remark reflects the fact that such treaties did not become invalid because of coercion in their conclusion. He is really saying that such treaties do not give more than the appearance of legality in a private law sense. Looked at in this way, Liszt's very concise argument is that acquisitive prescription could be a useful way in private law systems to resolve originally illegal or at least forceful possession of land in private law where a long period of uninterrupted possession has followed, but that the usefulness of the concept in international law is limited by the practice of conquest, the legal effect of which is generally resolved very openly and much more quickly. It works both ways in his analysis. A conquering state does not have to wait until a so-called time immemorial, while a victim state can be assumed to have tacitly consented to a loss of rights very quickly. In these types of situations the purpose of acquisitive prescription, to achieve stability or order, is achieved all the more quickly by other means more suited to the present condition of states. 21

The actual text of von Liszt concerning the second justification for not regarding acquisitive prescription as a law creating fact reads as follows. The ground for rejection lies:

"in der unmittelbar rechtsbegründenden Wirkung, die auf dem Gebiete des Völkerrechts die nackte Tatsache, daher auch die Gewalt, vor allem als Eroberung, hat. Die kriegerische Erwerbung eines fremden Staatsgebietes erstreckt, ganz abgesehen von dem Friedensvertrage, die Staatsgewalt des erobernden Staates ohne weiteres auf das neuerworbene Gebiet, ohne dass es einer Ersitzung im Sinne des Privatrechts, insbesondere also des Ablaufes eines längeren Zeitraums, bedarf; 
und wenn ein Staat ohne Widerspruch es zulässt, dass seine

Kolonien von einem andern Staat besetzt und verwaltet werden, so

muss ein Verzicht auf die ihm zustehenden Rechte angenommen

${ }_{21}$ For a German version, I choose the last edition for which von Liszt was responsible, the 11th of 1918, Berlin, Springer Verlag. Lauterpacht himself used the posthumous 12th edition of Fleischmann of 1925. The 11th edition is in this respect identical to the 4th and 9th editions.

[end of page 90]

werden, ohne dass erst die Verjährung seiner Ansprüche durch den Ablauf der Zeit abgewartet zu werden braucht. " 22

Von Liszt's work was regarded at the time as the most standard text in the German language.23 There was a French translation of the ninth edition (1913) arranged by the Carnegie Foundation, with a preface by James Brown Scott in 1927. Scott, in his preface, makes the vital point that the reason for the translation was that von Liszt's work was the most remarkable representation of a whole period of international law, which was brought to an end with the First World War. In other words it was representative of an epoch. It had to be taken alongside the works of Westlake, Bonfils, Fauchille and Lawrence as characterising the positivist epoch in which the dominant concept was the sovereignty of the state, accompanied by the traditional notion of suprema potestas, protecting absolutely the authority of the prince or minister, but constituting a real obstacle to the development of international law.24

Scott goes on to give his opinion that von Liszt's work was incomparably the best of its kind in the pre-War period. It had the further merit that von Liszt was a veritable precursor of the post-War period (he died in 1919). About half the book is devoted to studying the institutions states are developing to express their common interests in an international community. Scott notes that von Liszt does present a theory of war as the ultima ratio of the positivist period of international law before the War. However, Scott adds that it is necessary to take into account this traditional concept of law until the day when the evolution of international relations will be such that one will be able to oppose victoriously the sovereignty of law to the sovereignty of the state. 25

\section{The Reality of the State - A German Idea or a European Heritage}

The last discussion has been a useful introduction to the wider philosophical question whether there is no significant distinction between the problems of

22 F. von Liszt, Das Völkerrecht, p. 156.

${ }_{23}$ F. Herrmann, Das Standardwerk, Franz von Liszt und das Völkerrecht (Nomos, Baden, 2001) pp. 126-129. The method of this article is not biographical, but one might mention that Herrmann characterises von Liszt, who was politically active and participated in public debate about German war aims, was a left liberal, who opposed the view of the World War as a war of conquest.

${ }_{24}$ F. von Liszt, Le Droit International, traduction par Gilbert Gidel avec Leon Alcindor, Avant-propos de James Brown Scott (Pedone, Paris, 1927) p. vii. 25 Ibid., pp.vii-ix.

[end of page 91]

the rule of law at the national and the international level. In the entry on 
acquisitive prescription in the Max Planck Encyclopaedia of Public

International Law, it is mentioned that whether it existed, what it required, in terms of time limits, etc. "were classical subjects of contention".26 The arguments against the idea being part of international law concerned the level of development of the international legal order. Those opposed to the idea being part of the law thought international law not evolved enough - its concepts and institutions not sufficiently comprehensive, complex and robust - to support it. The idea behind this opposition was that it was better, given the centrality of the state, to treat the inactivity or silence of the state as equitable with implied waiver. Acquiescence places the decisive element in the behaviour of the state threatened, rather than in the lapse of time as such. It may have been thought a good idea for the preservation of order not to permit uncertainty through inactivity to be prolonged beyond a certain period of time.27 At any rate it is difficult to see how very great moral or political issues could be thought to hang on the question of the existence or non-existence of the private law concept of acquisitive prescription. States do not become any more harmless because a few arbitration law tribunals apply private law concepts to resolve their disputes.

In the theoretical part of Private Law Sources and Analogies of International Law, Lauterpacht identifies the Germans as the opponents of his wish that private law be regarded as a source of international law, particularly Holtzendorff and Bulmerincq in the late 19 th century.

Holztendorff objects that the analogy breaks down because private relations among persons are permanently subject to authoritative legislation.28 Bulmerincq asserts that the recourse to analogy has impeded the growth of international law.29 Neither provide elaborate justifications for their position, but Lauterpacht sees it as due to the fact that international law around 1900 stood where it was left with Hegel's theory of the state as an absolute end, as an absolute power on Earth, which cannot be subject to any will but its own. International law is then an external municipal public law of the individual state. In Lauterpacht's words, there is no general rule for the international community. Quoting Hegel, he says states are in relations with one another as in a state of nature: "Their rights are not realised in a general rule which is

${ }_{26}$ Entry by C. August in vol. 10 of the Encyclopedia of Public International Law, (North Holland, Amsterdam, 1987) p. 327.

27 Ibid., pp.327, 328.

28 Lauterpacht, supra note 9, p. 19.

29 Ibid.

[end of page 92]

so constituted as to have power over them, but their rights are realised only through their particular wills." This leaves, in Lauterpacht's words, no other law for the state but the purpose of its own self.30 Lauterpacht goes on to treat Lasson and Kaufmann as the key figures representing the mood of pre1914 Germany. 31 He does go so far as to say that beyond Germany this perspective was also dominant, although "British-American international law never became completely divorced from the conception of international law as embodying not only positive rules set by sovereign states, but also principles of legal justice, reason, and equity ..." 32 However, Lauterpacht thinks,

"it will serve no useful purpose to deny that the modern science of international law follows closely the Hegelian conception of State and sovereignty. Accordingly, it will not be found surprising that its expounders did not view with sympathy any larger reception of 
private law. For private law suggests subordination to an objective rule, and not a loose coordination of wills; it suggests interests valued by law and measured by it, but certainly not constituting the formal source and the ultimate legal foundation of its validity; it suggests mainly economic interests for the satisfaction of mainly economic wants, and not interests of a 'public' higher, absolute." 33

I submit that there are real difficulties in identifying and resolving the difficulties of governing international society if they are equated exclusively with a supposedly monolithic German, Hegelian tendency to deify the state. Lauterpacht first attempts to draw a German-British dichotomy and argue that the British avoid the mystical entity of the state. For instance, Westlake stresses that it is men upon whom international law imposes rights and duties, and not the mystical entity called the state.34 Indeed, Lauterpacht here quotes a variety of British constitutional theorists and legal historians for the proposition that mystical meant the notion that even the common legal idea of corporation could signify something "greater and wiser than the sum of the citizens who compose it", for "there is nothing in the State but what its members give it". He claims they go back to the founding tradition of international law, that the law of nations is addressed to individuals. Significantly, he is aware of the continued life of the civilian tradition in

30 Ibid., pp. 44, 45.

31 Ibid., pp. 47, 48.

32 Ibid., p. 49.

33 Ibid., p.50.

34 Ibid., p.80.

[end of page 93]

England, in the work of Phillimore, above all, for whom recourse to Roman law as right reason was natural. $35 \mathrm{He}$ addresses the idea that for Vattel the law of nature "is not less obligatory upon states than on individuals, because States are composed of men ..." 36 However, the distinction between a law of nations for individuals in the $17_{\text {th }}$ century as compared to the $20_{\text {th }}$ century is lost on him, and it will be necessary to come back to this in the section devoted specifically to the treatment of the domestic analogy in contemporary international relations theory.

Here Lauterpacht is misunderstanding the most basic reality of international society since at least the 17 th century that it consists of sovereign states, which are anything but voluntary associations of individuals, without any collective drive or impact apart from that attaching to individuals who compose it. He misunderstands as well that the absence of a world state problematises the place of law and morality in relations among states, to a degree different in kind rather than degree from the domestic relations of states, and he projects these blind spots onto a responsibility specific to German legal and political philosophy. In fact it is precisely the French who created, on the European continent, the modern state, through the theory of Jean Bodin. It is remarkable that Lauterpacht does note how the leading French international lawyers of his time, BonfilsFauchille (the leading contemporary text), Despagnet and others, "deal at length with the sources of international law and its relation with private international law, to morality, to international courtesy, to politics and diplomacy, but no mention is made of private law proper ..." 37 Lauterpacht was enough of a scholar to notice the discrepancy, but not open minded enough to explore it. For instance he notes that Bodin had a theory of absolute sovereignty of the state, but he simply reassures himself, 
on the authority of Verdross, that it was not the same as Hegel's, 38 which is true enough, but little consolation. Bodin's place has to be seen as an ideologue of a very problematic consolidation of the state from the 16th century onwards. Lauterpacht is, of course, right to identify a serious problem for international law, but wrong to identify it with Hegel as the originator. In the standard international law textbook, which has built into it an historical perspective, Cassese explains that from the 16th century, beyond the Roman Catholic Church and the Empire, remembering that the Protestant

${ }_{35}$ Ibid., pp. 26, 27.

36 Ibid., pp. 80, 81.

37 Ibid., p. 30.

38 Ibid., p. 44.

[end of page 94]

churches are purely national, all significations are concentrated in the state. This allows Cassese to say that the lack of strong political, ideological and economic links between states (as Christian principles were not allowed to override national interest) resulted in self-interest holding sway. 39 The absolutist state has had to mean the disappearance of a universal international legal order. In the period of transition from the medieval-feudal system of public authority over land and population to the modern absolutist state in the course of the 16 th and early $17_{\text {th }}$ centuries, the focus of public lawyers was on the terms of submission of subjects to rulers. The tradition that the central legal concept should be jurisdiction (of a lord over his vassals in his court) gave way to the more nebulous notion of the limits of the supreme power (potestas suprema), in effect, of an unconstrained executive. For this power to have sought or found justification would have meant looking to a law of the Holy Roman Empire or of the Papacy, as this was the traditional sense given to the existence of a higher authority. The authority of the prince was given a rationale by political theorists such as Bodin. 40 The very idea of absolute authority had to mean its separation from any argument of legitimacy of the relationship of ruler to ruled. The legal development marked a separation of the governing power from concrete legal relations, where primary importance was given to the concept of frontier as the means of delimiting the territorial scope of the prince's power.41 Territory came to be defined merely as the areas of command of the prince, with a supposedly unquestioning duty of the subject to owe submission to the prince. The difficulty, from the late $17_{\text {th }}$ century till the 20 th century, and particularly in the 18th century, was that the territorial princes of Europe did not obtain thereby a convincing legal foundation for their possessions, for instance land and population. The focus was simply on the advantages of internal order which would follow from a generalized submission. As a result there were ever-harsher territorial conflicts as the notion of the need for princely authority in political theory was not matched by an international-European consensus on the basis for territorial title at the international level. There had been a sacrifice of even domestic political legitimacy, for instance, based on the consent of the population in favour of the value of domestic public safety. This was understandable, in the context

39 A. Cassese, International Law (Oxford, 2001) para. 11. What follows in this section draws from chs. 3 and 4 of A. Carty, Philosophy of International Law (Edinburgh University Press, 2007).

${ }_{40}$ D. Willoweit, Rechtsgrundlagen der Territorialgewalt (Boelau, Cologne, 1975)

pp. 123-126, 129-131.

41 Ibid., pp. 275, 276. 
[end of page 95]

of bloody civil wars, for instance, after the Wars of Religion. However, safety was conceived of in purely internal and not international terms.42 In the 18th century Vattel made a decisive yet harshly contested entrance. Vattel is, of course, Swiss, but his influence became dominant in much of continental Europe in the 19th century, particularly in France. As a French historian of international law, Emmanuelle Jouannet demonstrates the same continuity of the medieval legal method throughout the 17th and early 18th century from Grotius to Vattel. All the major legal figures continue some version of the medieval method. The main figures are Grotius himself and what Jouannet describes as his disciples, Rachel, Zouche, Textor and Bynkershoek.43 The reason why international law had not until Vattel become an autonomous discipline in its modern recognisable form is rather surprising. Jouannet traces how none of the earlier jurists conceived of the state or nation, words used interchangeably, as a corporate entity distinct from the person of the government or the prince. There are traces of the idea of the state as a corporate entity in the writings of Hobbes, which have also exercised an influence on Pufendorf.44 However, even these two writers remained with the concept of government alone rather than developing a concept of a corporate entity, which embraced both the governor and the governed. The elements, which would make up the modern state in international law, i.e. government, territory and population, remained the property of the prince. He had a territory and a population, in a patrimonial sense. Such a personalised concept of authority directs attention to individuals and favours the retention of the medieval idea of a common law of human beings applied to the leaders of nations. Grotian style erudition prevails into the 18th century to regulate the affairs of princes, in their relations with one another, but also in their domestic and even private affairs. Lauterpacht does not realise that, at least in Jouannet's view, this world of individual law or morality is a lost past, which cannot be recovered, also the view of much contemporary international relations theory (see the next section).

It is with the Vattelian critique of Christian Wolff that one arrives at the modern conception of international law, where sovereignty as a legal concept comes to play a central part. Absolutely central is the notion of the

42 Ibid., pp. 306, 307, 349, 350, 360, 361.

${ }_{43}$ E. Jouannet, L'Emergence: Part II Autonomisation du Droit des Gens (doctoral thesis, Paris, 1993) pp. 141-147.

44 Ibid., pp. 300-324.

[end of page 96]

corporate character of the state. As a legal entity, it has to be separate from both government and governed. It is the state and not the government or prince which is subject to international law. It is and can be subject to international law only if it is sovereign, that is, equally independent of all other states.45 What Jouannet is, above all, anxious to stress is that law should have a dualist character in what she calls the classical form of international law. It is essential to the idea of the corporate character of the state that there should be no relations of individuals with one another across state boundaries. All the relations of individuals, for the purpose of international law, are absorbed into the corporate identity of the state, which then has legal relations with other states. In this way it is the sovereign 
equality of independent states which defines the object and scope of the rules of international law.

This is precisely what creates the need for institutions of law particularly suited to the legal character of the state as such, and not the relations of private individuals. This remains a central thesis of continental European public international law. Yet, unlike Lauterpacht, Jouannet sees no difficulty in the Vattelian sovereign being integrated into an international legal order. The lack of difficulty is hardly surprising because this new legal order is made by states specifically for their relations with one another.46 It is because states have no rights over one another that they have need of a law which recognises that they are independent and equal.47 In other words, there need be no inhuman, violent or threatening consequences in the expectation that states need laws especially suited to their character rather than to that of private individuals. That is why the French international lawyers mentioned by Lauterpacht give no attention to private law. Jouannet appears to see the entire exercise as taxonomy of what relates or properly belongs to the rights and duties of nations rather than individuals. The idea that there should be rules specifically designed for the character of sovereign states can hardly pose problems of legally binding character.48 The aim of this taxonomic exercise is to register a break with the Roman and medieval tradition of law. The progressive character of this law is that it incorporates the two great principles of liberty and equality of states as the very basis of the society of nations in place of the genre humain (human kind) of the

45 Ibid., pp. 354-388, especially 384 et seq.

${ }_{46}$ J. Bartelson, A Geneology of Sovereignty (Cambridge, 1995) pp. 137-185, a summary of chapter 5 , How policy became foreign.

47 Ibid., pp. 194, 195 (author's emphasis).

48 Jouannet, supra note 43, p. 447.

[end of page 97]

naturalists. Now the nation can govern itself without dependence upon what is foreign to it. 49 The constant theme of this argument is the corporate character of the sovereign. Because sovereign nations deal only directly with one another, they can only see one another as societies of men of whom all the interests are held in common. It is not a law of nations derived from human nature which rules them, but a law derived from the particular nature of the state.50 Here, Vattel, not Hegel, provides a very elaborate rejection of the law of nature, as it applied to individuals in the earlier international law tradition of Grotius, etc., to his modern international or inter-state law. None of this is to say that Lauterpacht is mistaken to be uneasy about the idea that states have a unique character, distinct from individual human beings, which requires a law appropriate to them. The point is simply that this juridical direction is not attributable to German international law science. It is so interesting to give a prominent place to Jouannet's argument because she reflects well the fact that many international lawyers are so little troubled by the concept of sovereignty. She is aware of the problem of subjective appreciation but manages to make it appear that those who stress it misunderstand the structure of international law and lack the technical expertise to understand how it is supposed, following its own nature, to function. Jouannet admits that Vattel keeps the principle of the subjective appreciation of each state in the application of the law,51 but considers it is unjust to make him responsible for the increasing voluntarism of international law.

Voluntarism means that all of the body of international law depends 
upon the continuing consent of states. They can, at any time, cease to accept that a rule binds them, and even cease to recognise other states as subjects of the law. Vattel is not responsible for such a view. He merely introduces the logic of Hobbsean and Lockean individualism into international law, in terms of the liberty and sovereignty of states as the foundation of international law.52 A doctrine of the autonomy of states is not a doctrine of absolute or unlimited external sovereignty. It is not a non-submission to a superior juridical order but an autonomy of a political entity vis-à-vis other equally independent entities. The root of the confusion, in Jouannet's view, is to have made a too rapid combination of the question of the application of

49 Ibid., p. 448.

50 Ibid., p. 451.

${ }_{51}$ Ibid., pp. 454-458.

52 Ibid., pp. 458, 459.

[end of page 98]

international law with the decentralised structure of the community of states. There is no compulsory international adjudication. So states have to interpret for themselves the extent of their rights. She says the question of the subjective appreciation of the law is not an aspect or logical consequence of voluntarism in international law, a doctrine that all law is a product of state will, but arises from the conditions for the application of the law in a decentralised international legal order. International law is a universal-abstract law, but appreciated unilaterally because subjectively and therefore it functions in practice as a series of reciprocal and bilateral interpretations given to it by states. Vattel simply marks a reflection of a change at an international level which had been occurring generally in legal culture - a movement towards individualisation and subjectivisation of law, combined with a realist vision of international relations where states have a mission to act to assure their security and preserve their interests. It is not Vattel who introduces this subjectivity into international law. It is simply an unavoidable fact of international law in the absence of any supra-state power. So, in the beginning and middle of the 20th century it is not this subjectivist, decentralised appreciation inherent in the structure of the international community which is the problem, but the legitimacy of the use of force which accompanies it.53

Of course, Lauterpacht is perfectly entitled to be less sanguine about the prospects for humanity of an exclusively inter-state law. Indeed, it is worth considerable reflection that James Brierly, Lauterpachts's virtual contemporary in England, was equally upset about the general condition of international law after the First World War, but perhaps ironically, he, as a native Englishman, seemed to believe that the fault lay with the French. Of course, Vattel was not French, but Brierly's polemic against him was in the context of his apparent, and in Jouannet's case, continued appropriation by the French. In his magisterial introduction to international law, The Law of Nations, Brierly quotes at length the French international lawyer Albert De Lapradelle on the significance of Vattel, whose text Le Droit des gens, published in 1758 , is usually regarded as the standard founding statement of modern international law. The Frenchman praises Vattel for having written in advance of the events, which the book represents, the principles of 1776 and 1789 of the American and French Revolutions. Vattel is credited with

53 Ibid., p. 472.

[end of page 99] 
projecting onto the plane of the law of nations the principles of legal individualism. Vattel has written the international law of political liberty. 54 Brierly comments astutely that the survival of the "principles of legal individualism" has been a disaster for international law. The so-called natural independence of states cannot explain or justify their subjection to law and does not admit of a social bond between nations. Vattel has cut international law from any sound principle of obligation, an injury that has never been repaired.55 The brief focus here will be on Brierly's critique of Vattel on the use of force since it is most relevant to concerns about the inhumanity of inter-state law. Vattel makes each state the sole judge of its own actions, accountable for its observance of natural law only to its own conscience.56 This reduces natural law to "little more than an aspiration after better relations between states ..." ${ }_{57}$ For instance, by necessary law (natural law) there are only three lawful causes of war: self-defence, redress of injury and punishment of offences. By voluntary law (effectively the positive law based on consent) each side has, we must assume, a lawful cause for going to war "for Princes may have had wise and just reasons for acting thus and that is sufficient at the tribunal of the voluntary law of nations ..." 58 Brierly is telling us that the very categories of thought which the international law tradition since Vattel offers makes it impossible to think of that law effectively restraining the recourse of states to violence. However, Brierly appears to point the finger at the very foundations of individualist Western legal and political culture when attributing responsibility for the crisis. Brierly attacks the very individualism which Lauterpacht appears to think is progressive as an anarchistic and nihilistic force. Clearly he sees no place for private law analogies and worked instead in his life for a revival of an objective natural law.59

54 J. Brierly, The Law of Nations (Oxford University Press, Oxford/Boston, 1963) pp. $39,40$.

55 Ibid., p 40.

${ }_{56}$ Ibid., p 38.

57 Ibid.

58 Ibid., p 39.

${ }_{59}$ For the most exhaustive account of this aspect of Brierly, see J. Nijman, International Legal Personality (Nijhoff, Boston, 2004) ch. 3.

[end of page 100]

\section{Private Law Analogy: Could Lauterpacht Have Addressed Standards of International Morality More Directly?}

In this short essay it is only intended, by way of conclusion, to raise some general questions about what Lauterpacht was trying to achieve with Private Law Sources and Analogies of International Law. His general conviction, in what one might perhaps call progressive, ideological terms, is to insist that states must be subject to the same standards of behaviour, whether characterised as moral or legal, as individuals. The main difficulty in achieving this is the Hegalian value attributed to the state, which gives it such a superhuman status that it can be absolved from normal standards of human behaviour. The main remedy, and at the same time proof of the falseness of Hegelianism in technical international law terms, is the recognition that the international legal order, and particularly judicial and arbitral tribunals, actually apply private law analogies in resolving inter-state legal disputes. My reflection on these arguments is that the legal practice to which Lauterpacht refers has nothing progressive or humane about it, and 
that Lauterpacht misidentifies the nature of the problem of the overbearing state by attributing it exclusively to German Hegelianism.

The question is whether and how to take the matter further. As I have argued in, and since, the publication The Decay of International Law?,60 the level of conceptual, historical and philosophical debate about the discipline of international law is so ossified in most European countries that a work of such intellectual ambition as Lauterpacht's above-mentioned work can be published without provoking any intelligent discussion whatever, apart from the general adulation which seems to accompany anything Lauterpacht has done.61 The same is not true of the discipline of international relations, which is in an infinitely more intellectually healthy condition in Britain. From the beginning, one of its most senior protagonists challenged Lauterpacht, and Lauterpacht, at least, gave serious thought to responding. Perhaps if he had directed more of his energies to his international relations opponents and less to his own profession, he might have been stimulated to presentations of his views on states and private morality which could have had a resonance wider than international law circles.

To repeat the argument stated more than 20 years ago in The Decay of International Law, Lauterpacht thought private law analogies could be expected to play a large part in the development of international law because

60 A. Carty, The Decay of International Law? (Manchester University Press, 1986). ${ }_{61}$ This is not true of Finland and Koskenniemi's scrupulously close, if nonetheless very benign, reading of Lauterpacht. [The following note is not part of the printed version: I have more in mind James Crawford's very generous but, in my view, vague statement: "With his extraordinary productivity and high seriousness, Lauterpacht was the most significant writer on international law in the period 1920-1960 and not only in Britain”. J. Crawford, 'Public International Law in Twentieth Century England', in J. Beatson and R. Zimmerman (eds.), Jurists Uprooted, German Speaking Émigré Lawyers in Twentieth-Century Britain (Oxford University Press, Oxford, 2004) p. 681.]

[end of page 101]

such, in effect, judicial activity could only be understood in the wider context of a commitment to the goal of international organisation. Jurists drew analogies between international and municipal law concepts within a framework which was to replace the politics of international relations with institutions approximating as far as possible to those of a world state.62 Already in 1939, E. H. Carr objected that Lauterpacht did not complete his own argument, that judges in adjudication could determine any question if states wished by showing how arbitration could still be promoted in a noninstitutional system where political disagreements remained basic. For instance, at that time, the Soviets rejected the idea of private ownership, and the UK rejected the limits on a law of blockade at sea. In particular, Carr argued, jurists had not studied the suitability of the private law analogy itself, apart from the institutional framework in which it was born: "[T]here is no principle of law which enables one to decide whether a rule of law or legal institution which has proved its value in a national community should be introduced by analogy into international law." 63 Carr pinned down the nature of the problem in a manner which has been taken up continuously in post-War international relations debates. He says the problem about the application of law to the settlement of disputes is, in its final analysis,

"the fundamental one of the relation of the rights of the individual to the needs of the community. Every national community has necessarily found a working solution of this problem. The international community has not yet done so. The controversy 
about the freedom of the seas shows that Great Britain would be unwilling to risk any interpretation of her maritime rights by an international court in the light of the supposed needs of the international community as a whole; and there are important matters on which every other Great Power would make similar reservations. The absence of an accepted view of the general good of the community as a whole overriding the particular good of any individual member of it, which we have already noted as the crucial problem of international morality, also stands in the way of the development of judicial settlement in its application to international disputes." 64

${ }_{62}$ Carty, supra note 60, p. 80.

${ }_{63}$ E. H. Carr, The Twenty Year's Crisis, 1919-1939, 2nd ed. (Macmillan, 1946) p. 199.

64 Ibid., pp. 198, 199.

[end of page 102]

Lauterpacht was certainly aware of Carr's book. There is a paper entitled Professor Carr on International Morality.65 Here Lauterpacht identifies the question directly, assuming the reality of the personality of the state, whether that reality can be maintained consistently with upholding a single standard of morality for states and individuals. It does not follow from the reality of the state "that the obligations of states are not the obligations of individuals acting on their behalf; and that the morality of states is different from the morality of individuals".66 Lauterpacht observes what is precisely at issue is not some abstract argument that group personality is entirely distinct from that of its component parts, a controversial thesis. Rather, the group, even if it is a legal fiction, is a convenient instrument of thinking.

Lauterpacht nails the problem in the fact that

"[ $t]$ he existence of a group is a powerful inducement to laxity in conduct. The opportunity to shift the burden or moral doubt upon the impersonal shoulders of the amorphous association is a motivating force in the nature of a temptation, which only a most scrupulous fortitude of mind and principle can hope to overcome with ease. There is nothing mystical about the group. But there is about it the constant threat of the suggestion that it represents an interest greater in the scale of values than the private interest of the acting individual. From this there is only one step to the view that the individual is entitled to gauge the action to be taken by a standard different from that which he would be bound to adopt if he acted on his own behalf. From this it is only another step towards the final view that the individual is not at liberty when acting as a trustee for others to afford the luxury of private morality. This particular argument has been repeatedly put forward. A moment's consideration shows that the argument is grotesquely inadequate. It is difficult to understand why the interests of other persons on behalf of whom we are acting should be so different and so much higher in the scale of values than our own as to warrant the adoption of different moral standards." 67

This is surely a lucid undercutting of the traditional Machiavellian argument that the prince must judge the interests of a collective differently from how he would judge his own. Lauterpacht identifies the devious and venal

65 H. Lauterpacht International Law: Being the Collected Papers of Hersch Lauterpacht, E. Lauterpacht (ed.) (Cambridge University Press, 1975) vol. 2, part I, p. 67. 
${ }_{66}$ Ibid., pp. 69, 70.

67 Ibid., p. 76.

[end of page 103]

character of such reasoning. He mounts a critique of the whole picture of the 1930s that Carr draws, and argues that there is no consistent empirical evidence that contemporary democracies will accept double standards in international life and manifestly, morally ruthless behaviour of one's own country in relation to other countries - a lynchpin of Carr's argument that there is no international standard of the common good. In Lauterpacht's view, it is precisely because in the final analysis, the individual remains the ultimate unit of government and state action, that "the doctrine of duality of moral standards has never struck deep roots in democracies".68 Lauterpacht's formulation of his case is very shrewd. He is not presenting a doctrinaire argument about the moral superiority of democracies. Democracy is not the best instrument for operating a long-term foreign policy. "It does not exhibit a temerity of purpose and a degree of foresight necessary for the effective organization of an international system of peace and collective security." 69 Deficiencies of collective memory mean democracy will fail "to exhibit the necessary loyalty and fidelity to obligations undertaken on its behalf in the field of collective security". 70 However, where an issue of deliberate immorality of government officials, ostensibly in the national interest of their own country, comes clearly to the attention of the wider public in a democracy, one must hardly be surprised if there is an upsurge of outrage in the country which sweeps away the government officials. This will not happen with absolute consistency, but it will be frequent enough to disturb and unsettle the whole idea of realpolitik.

Lauterpacht takes the example of the Hoare-Laval incident. Hoare was himself publicly denounced of a "terrible crime". Public outrage at the Hoare Laval Plan, in the context of the Italian-Abyssinian War, was so intense "that it swept like a cleansing breeze through the entrenched citadel of a Government supported by a powerful and docile parliamentary majority". 71 With great simplicity, Lauterpacht nails the issue. Just as if I cheat or bully in the course of a game in the interest of my team, or for friends and family I resort to cheating or lying, I still act immorally. So it is also the fact "that popular feeling spontaneously and almost invariably disapproves of any manifestations of or attempts at inferior international morality". 72 There is a more abstract aspect to the disagreement between Lauterpacht and Carr, which is more difficult to pin down, where Lauterpacht is not so

68 Ibid., p. 74.

${ }_{69}$ Ibid.

70 Ibid.

71 Ibid., p.71.

72 Ibid., pp. 71, 72.

[end of page 104]

convincing, and that is in his espousal of the philosophy of political liberalism, whether located nationally or internationally. This is a point, as we have seen, that Koskenniemi identified as being at the heart of Lauterpacht's basically progressive optimism, based upon a methodological, economic individualism. Carr argues that " $[t]$ he conception of morality implies the recognition of principles of a universally binding character". 73 The way to resolve contradictions between our own national interest and an international interest is either to identify the good of the whole with the good 
of the fittest (Hitler's philosophy) or the neo-liberal doctrine of the harmony of interests. The latter approach is espoused by Woodrow Wilson, Lord Cecil and Professor Toynbee. Carr makes a critique of the latter, which is especially poignant at the present time. He identifies the Achilles Heel of Anglo-American "international morality", which is that national morality is comparable to individual morality in being equally self-deceptive and egoistic. The doctrine of neo-liberalism, "like every doctrine of a natural harmony of interests, identifies the good of the whole with the security of those in possession". ${ }_{74}$ Wilson's view that American principles are those of mankind and Toynbee's that the British Empire's security was the supreme interest of the whole world, were the same as Hitler saying that Germans were the bearers of a higher ethic. So, argues Carr, "the same result is produced of identifying the good of the whole international community with the good of that part of it in which we are particularly interested".75 Carr quotes Hobhouse as saying that liberalism has an ethical component which has to accommodate inevitable conflicts of interest by supplementing prudence and judgement with a specifically ethical element. This is the breaking point for Carr. The constellation of interests in international society will reflect hegemony, and if the hegemony is to survive there must be a willingness to make sacrifices to those who are dissatisfied with the status quo and want changes. This is impossible to achieve if one assumes, as do the satisfied powers, that the process of give-and-take operates only within the existing order and that one's own interests as a satisfied power are identical with those of the whole world. This is effectively Britain's position. Carr quotes Anthony Eden as saying that international peace depends upon an international order with nations leagued together to preserve it. Each nation makes its contribution because therein lies its own interest. This

${ }_{73}$ Carr, supra note 63, p.166.

74 Ibid., p. 167.

75 Ibid.

[end of page 105]

ignores the fact that "the process of give-and-take must apply to challenges to the existing order".76

Lauterpacht's reaction to this argument has several elements, writing in 1941 he can dismiss out of hand an equation of the pronouncements and conduct of Hitler's Germany with those of Britain, the United States and other democracies. $77 \mathrm{He}$ adds to this a bold statement that no serious criticism can be made of the diplomatic history of either the United States or Britain. 78 The desire of such countries for international order and organisation may be identified, as Carr does, with a hypocritical desire to preserve national interest, but "it is also possible to see in their advocacy of an effective rule of law among nations a summons to the creation ... of the orderly processes of a politically organised community". $79 \mathrm{He}$ identifies the British and American approaches to world society as "based upon the view that the supreme national interest is identified with the rule of law among states, with a submission to the impersonal sovereignty of the law, with the willingness to forgo progressively rights of sovereignty for the sake of the greater whole ultimately beneficial to the component parts". 80 In my judgement the most fundamental element of Lauterpacht's argument is ironically - and he is vaguely aware of the irony - that he sets much lower standards of morality than Carr, and he is complacently nationalistic throughout. He cannot achieve the detachment from his adopted country's national goals which comes so easily to Carr. He says, contrary to 
Carr, that the inability of the state to show altruism and self-sacrifice is irrelevant:

"Self-sacrifice and altruism in the nature of self-sacrifice are not the basis of private morality. Morality does not enjoin us to sacrifice our life and interests for the good of others ...81

Contrary to Professor Carr's view, the frequently asserted right of selfpreservation of the state need not override its moral obligations. Undoubtedly, the appeal to the right of self-preservation has often been abused, but there are clearly cases in which an appeal to the right of self-

76 Ibid., pp.168, 169.

77 Lauterpacht, supra note 65, pp. 88, 89.

78 Ibid., pp.72, 73. Having said it is a dangerous question to ask whether Britain's conduct was ever clearly immoral, Lauterpacht admits the question must nevertheless not be shirked. Yet he concludes a not surprisingly brief diplomatic survey by saying: "I must leave to others to inquire into the immorality of British foreign policy."

79 Ibid., p. 90.

80 Ibid., p. 89.

81 Ibid., p. 79.

[end of page 106]

preservation, although violative of the legal rights of another state, is not inconsistent either with legal or moral obligations. International law fully recognises the right of a state to override, in certain contingencies, the legal rights of other states. If the seizure of the Danish fleet in 1807 had been brought about as a result of a justifiable belief that the very existence of Great Britain was at stake, the action would not have been inconsistent either with international law or international morality. The only question which has divided writers on this point was whether the emergency was in fact such as to justify the action taken ..." 82

Lauterpacht himself concludes his argument against Carr, at times somewhat bitter, on a light and ironical note. Carr thinks self-sacrifice from states is necessary for international peace, but unlikely to be forthcoming. Lauterpacht thinks self-sacrifice would not be forthcoming, but is in any way unnecessary generally in constructing morality and unnecessary in international society because of the fine character of the British and Americans.83 Elihu Lauterpacht says that he was reluctant to publish Professor Carr and International Morality, a manuscript probably written in 1941, because of its polemical tone and relatively unrestrained style. However, he decided to do so because the work sheds light on Lauterpacht's own positive views. 84 I am only glad that he has done so. I have paid no attention to the rather harsher comments that Lauterpacht makes about Carr, partially because throughout this short article I have not endeavoured to be biographical, but have tried to stick to the texts themselves. To my mind the most important and most unfortunate aspect of this last work is that it was not published at all. This had the effect that the leading international lawyer of mid-20th century Britain did not engage in open controversy with the most important specialist of international relations in the country. If a debate had ensued Carr invited it with the frequent criticism of Lauterpacht's work in his own book - then it might have been possible that the two disciplines could have made a joint effort to grapple with the problems that both recognised, 
although the perception has always been sharper on the side of international relations.

82 Ibid. . p. 83.

83 Ibid., p. 89 (containing the quotation attached to footnote 80) and p. 92.

84 Ibid., p. 67.

[end of page 107]

It might be not without interest to conclude with a few remarks about how the debate among international relations scholars about the "domestic analogy" has been conducted since 1945. The authoritative Hedley Bull understood that to mean "the argument from the experience of individual men in domestic society to the experience of states ... The conditions of an orderly social life, on this view, are the same among states as they are within them: they require that the institutions of domestic society be reproduced on a universal scale ...". 85 The possibilities of dialogue are raised only to be dismissed fairly quickly. Suganami quotes an instance of domestic analogy in legal reasoning. D. W. Bowett had argued that the right of collective self-defence under Article 51 of the UN Charter could not be exercised by a state which could not legally have exercised a right of individual self-defence in the same circumstances. This interpretation, says Suganami, following Michael Akehurst, was based on analogies from English law that it would not allow one person to use force in defence of another unless there was a close relationship, for example a family relationship, between the two persons concerned. 86 These indications from Bowett and Akehurst hint of the wealth of material which might be uncovered if one were to explore the "citation history" of Private Law Sources and Analogies of International Law in British international law scholarship and Foreign Office legal advising.

However, Suganami is immediately dismissive of this rather promising attempt of Bowett to apply common law reasoning to international society. He says:

\footnotetext{
"Bowett's argument is advanced as an interpretation of existing law, and therefore it is a legal argument. Although the boundary line between what is to count as an interpretation of existing law and what is in effect an argument de lege ferenda may in some cases be obscure, municipal law analogies which occur within the framework of international legal discourse, purporting to state what the law is on a given issue, may be separated from what writers on international relations normally mean by the "domestic analogy". For this we need to look into projects for the reorganization of international society.
}

${ }_{85} \mathrm{H}$. Suganami, 'Reflections on the Domestic Analogy: The Case of Bull, Beitz and Linklater', 12:2 Review of International Affairs (1986) p. 145. 86 Ibid., p. 147.

[end of page 108]

One such project is found in the writings of James Lorimer...According to him, the ultimate problem of international jurisprudence was to find international equivalents for the factors known to national law as legislation, adjudication and execution." 87

This is clearly an intellectual move dominated by the academic hierarchies 
of the post-War discipline of international relations in Britain. The issue has been defined in institutional terms by that discipline, i.e. not whether there were common moral, legal normative or whatever standards which could be transferred from the domestic to the international level, but whether domestic institutions of statehood could or should be replicated globally. Hence, Suganami sees no paradox in ending his dismissal of international law with a reference to the relevance of a programme of an international lawyer. The question then becomes: how much international organisation do we need? Hedley Bull himself said that we had to abandon the domestic analogy because international society is unique and owes its nature to qualities peculiar to the situation of sovereign states. 88 At the same time Suganami wants to keep the door open for resort to domestic analogy, objecting to one "uncritically extending the prevalent belief in the limitations of institutional domestic analogies (which in turn may deserve a more careful examination than is usually given) to other forms of argument which, while in some way resembling the domestic analogy proper, are in fact logically distinct from it". 89 However, any pathway back to Lauterpacht will probably remain barred because Suganami accepts the sovereign state system as the starting point and then considers whether the domestic analogy is a useful inspiration for attempts to go beyond this in the League of Nations and the United Nations.90 Lauterpacht, as Carr identified, thought he could proceed with, effectively, international judicial government alone, based upon the resources especially of private law. The reason for this was, as already stated, that individuals managed states, just as they managed social, family and private matters. It was one common world. Lauterpacht began his book by calling upon the example of the founders of the discipline of international law, Gentili, Grotius and

87 Ibid., pp.147, 148.

${ }_{88}$ C. Bottici, 'The Domestic Analogy and the Kantian Project of Perpetual Peace' 11 The Journal of Political Philosophy (2003) p. 392.

89 Suganami, supra note 85, p. 156.

90 H. Suganami, The Domestic Analogy and World Order Proposals (Cambridge University Press, Cambridge, 1989).

[end of page 109]

Bynkershoek.91 However, Lauterpacht shows no awareness that such legal experience might become irrelevant after the system of sovereign states had been fully consolidated, except to argue that "things went wrong when the Germans came along". 92

In contrast, Suganami rejects as historically distinctive the natural law writers of the early modern period, whom he acknowledges did use municipal law sources, Roman ius gentium in particular. He quotes Holland as saying that international law was the application to nations of legal ideas, which originally applied to individuals. Yet Suganami realises that this world was dominated still by the belief in natural law:

"It is questionable, however, whether very early writers considered their legal reasoning as being analogical when they asserted that certain principles governed the relations of sovereigns. These principles, in their view, were axiomatic and governed human conduct universally. It was because of this universal validity that, in their view, Natural Law governed international relations." 93 
Law, Koskenniemi says that by "conducting his study in the form of an examination of practice, Lauterpacht is able to attack voluntarist positivism on its own terrain of scientific factuality without having to resort to the moralizing rhetoric of naturalism or the formalism of the pure theory of law". .94 I have no idea what is meant by scientific factuality or the moralising rhetoric of naturalism. However, I find that when Lauterpacht abandoned his fascination with imperialist arbitrations or his obsession with the eternal wickedness of Germans, and directed a dispassionate moral irony against the sophistry of Carr's apologies for the disgraceful behaviour of European states in the late 1930s, he was at his most inspiring and convincing. In my view Lauterpacht's exposure of the sophistries of individual immorality ostensibly practised on behalf of the group is natural law reasoning at its best, a discursive narrative which uses a Socratic irony to make the presence of moral standards obvious to everyone. I think he could have spent his time better in such activity than as an academic lawyer and international judge.

91 Lauterpacht, supra note 9, pp.10-16.

92 Ibid., pp. 17 et seq., Modern International Law. The Positive School in Germany. 93 Suganami, supra note 85, p. 149.

94 Koskenniemi, supra note 2, p. 365.

[end of page 110]

The general intellectual health of post-War Britain would have benefited if he had pursued Carr as relentlessly as Carr had pursued him. Maybe it was because of his adopted status in British society, a welcomed immigrant from Eastern Europe, that, as his son writes, "Lauterpacht normally avoided the public pursuit of controversy". 95

95 Lauterpacht, supra note 9, p. 67. 